УДК 339.923.061.1

DOI: https://doi.org/10.37320/2415-3583/16.11

Луценко I.C.

кандидат економічних наук, доцент, доцент кафедри менеджменту

Національний технічний університет Украӥни «Київський політехнічний інститут імені Ігоря Сікорського»

\title{
ЄВРОІНТЕГРАЦІЯ ЯК ЧИННИК РОЗВИТКУ ТРАНСПОРТНО-ЛОГІСТИЧНИХ КЛАСТЕРІВ В УКРАЇНІ
}

У статті розглянуто перспективи кластеризаџї транспортно-логістичної системи України, проаналізовано основні характеристики транспортно-логістичних кластерів, сформовано парадигму державного регулювання транспортно-логістичних кластерів та визначено ї̈ необхідність, особливо на етапі розвитку кластера, визначено основні інструменти держсвної підтримки. Із метою визначення ефективності процесів кластеризаиії економіки розглянуто досвід європейських краӥн щодо створення і функціонування транспортно-логістичних кластерів, визначено їх важливість для кластеризації всієї економіки. Транспортно-логістичні кластери розглянуто з погляду регіонального підходу і підвищення ефективності функціонування інших видів кластерів за рахунок створення надійного каркасу перевезень продукиї і надання логістичних послуг. Запропоновано прискорити процес розвитку проблемних ринків і регіонів Украӥни через створення транспортно-логістичних кластерів.

Ключові слова: транспортно-логістичний кластер, кластеризація, державне регулювання транспортнологістичних кластерів, євроінтеграчія, регіональний кластер, портовий кластер.

Постановка проблеми. Розвиток економіки України та іiі рівноправне партнерство у світовому господарстві забезпечуються інтеграцією нашої країни в систему міжнародних торговельно-економічних зв'язків і кластеризацією економіки.

Ураховуючи геополітичне і геоекономічне становище України, необхідно враховувати транспортнологістичну інтеграцію, іiі структуру, компоненти та регіональні програми. Надзвичайно важливо надати інноваційно- інвестиційного, якісно-професійного розвитку економіці України. Використовуючи досвід розвинутих країн, можна впевнено констатувати, що ефективним шляхом досягнення перерахованих цілей може бути кластеризація економіки саме через створення транспортно-логістичних кластерів.

Аналіз останніх досліджень і публікацій. Теоретичним і практичним питанням транспортно-логістичної кластеризації та підвищення на іï основі рівня розвитку соціально-економічної сфери, участі у глобалізаційних та інтеграційних процесах присвячено роботи М. Портера, І.Г. Смірнова, Я.Б. Олійника, С.В. Саркисова. Доцільність утручання держави у процеси формування транспортно-логістичних кластерів і ступень державного впливу висвітлено в наукових працях Ю.Ю. Гайворонської, С.І. Гриценко, O.І. Дмитрієвої, В.В. Шамаєва. Деякі питання формування транспортно-логістичних кластерів потребують подальшого аналізу, зокрема особливості державної підтримки на основі розроблення цільових регіональних програм в умовах євроінтеграції.

Метою дослідження $є$ аналіз специфіки формування транспортно-логістичних кластерів у країнах ЄC, впливу кластеризації транспортно-логістичної інфраструктури на активізацію розвитку економіки регіону та його інтеграційні процеси, визначення етапу та рівня державного впливу на процес кластеризації.

Виклад основного матеріалу дослідження. Сьогодні в Україні спостерігається парадоксальна ситуація: $з$ одного боку, виявляється надзвичайна нестабіль- ність і непередбачуваність роботи ланцюгів поставок, особливо міжнародних, максимально збільшується залежність конкурентоспроможності від швидкості та гнучкості реакції ланцюгів поставок на потреби кінцевих споживачів, з іншого - по суті, немає розробленої концепції, стратегії, програм та моделі розвитку транспортно-логістичної системи України, які були б підкріпленні фінансуванням. Така ситуація триває вже багато років, і це притому, що головною передумовою інтеграції України до загальносвітової економічної системи $\epsilon$ високий рівень розвитку транспорту. Для розбудови транспортної системи країни необхідно мати високий рівень розвитку техніки, логістично-інформаційних технологій, творчий і економічний потенціал населення, високий рівень кваліфікації, ефективне правове регулювання економічної і соціальної сфери.

Єдиним шляхом до змін на такому рівні має стати кластеризація національної економіки, що, до речі, впливає не лише на ефективність та конкурентоспроможність української економіки та ії̈ суб'єктів, а й на отримання відповідного геополітичного та геостратегічного положення, що $є$ надзвичайно важливим, коли наша країна знаходиться у стані війни з Росією.

Відповідно до теорії кластеризації М. Портера, кластери - це географічно близькі групи взаємопов'язаних компаній та асоційованих установ в окремій галузі, що пов'язані спільними технологіями та навичками. Вони зазвичай існують у географічній зоні, де комунікації, логістика та людські ресурси є легкодоступними. Кластери звичайно розміщуються в регіонах, а іноді - в окремому місті [1]. Кластеризація є ефективним інструментом стимулювання розвитку економіки, міжнародних відносин, підвищення інноваційного складника, збільшення зайнятості в країні та розвитку конкурентоспроможності. Основними передумовами створення кластерів $\epsilon$ : близькість ринку, забезпечення спеціалізованої робочої сили, наявність постачальників капіталу та обладнання, доступ до специфічних природних ресурсів. Якщо аналізувати інструменти 
підвищення ефективності економіки $\mathrm{CC}$, то процеси кластеризації активно використовуються у ключових секторах і сфері послуг, зокрема транспортно-логістичних. Більшість учасників транспортно-логістичного кластера відноситься за функціями, які вони виконують у транспортній галузі і сфері надання послуг, до складських, експедиційних, митних, логістичного консультування, фінансово-страхових. Це визначає міжгалузевий характер транспортно-логістичних кластерів. Формування транспортно-логістичних кластерів відбувається, як правило, на різних рівнях, при цьому географія охоплення може бути регіональною, країнною, у зоні міжнародних транспортних коридорів, тобто кластер може мати відповідно регіональний, міжрегіональний, національний і глобальний характер. Перераховане вище віддзеркалює максимально складну та змішану структуру транспортного-логістичного кластера, його важливість як зв'язуючої ланки і каркасної основи для проведення ефективної кластеризації всієї економіки.

Транспортно-логістичні кластери, так само як і економічні, мають такі характеристики:

- географічна концентрація (близько розташовані фірми притягають один одного можливістю економити на швидкій економічній взаємодії, обміні капіталом і інтегрованим процесом навчання);

- спеціалізація (кластери концентруються навколо певної сфери діяльності, до якої мають відношення усі учасники);

- множинність економічних агентів (кластери й їхня діяльність охоплюють не лише фірми, що входять у кластер, а й громадські організації, академії, інститути, сприяючі кооперації і т. д.);

- конкуренція і співпраця (основні види взаємодій між фірмами - членами кластера, які властиві їм рівною мірою);

- досягнення необхідної «критичної маси» у розмірі кластера для отримання ефектів внутрішньої динаміки розвитку;

- життєвий цикл кластерів (вони розраховані на довгострокову перспективу);

- залученість в інноваційний процес (фірми і підприємства, що входять до кластера, зазвичай включені в процеси технологічних, продуктових, ринкових і організаційних інновацій) [2].

Процеси транспортно-логістичної кластеризації в країнах ЄС спрямовуються передусім на підтримку діяльності Пан'європейського транспортно-логістичного простору. Так, у Нідерландах діяльність транспортно-логістичних кластерів приносить 40\% доходу транспортного комплексу, у Франції - 31\%, у Німеччині - 25\%. У цих країнах частка логістичних послуг в економіці є однією з найбільш значущих. Лідирують за кількістю зайнятих у транспортно-логістичний сфері Німеччина, Італія, Іспанія, Франція, Великобританія [3, с. 93]. Це країни, які утворюють так званий «Блакитний банан» - території Бельгії, Німеччини, Нідерландів і Швейцарії, це найбільш густонаселені райони Європи. У цьому регіоні сконцентровано приблизно 120-130 млн осіб, інша назва, яку має ця територія, - «європейський економічний хребет». «Блакитний банан» має хороші перспективи для подальшого розвитку: за прогнозними оцінками, у найближчі роки він географічно та економічно охопить територію до Риму. Привабливі для великих інвестицій райони сприяють розширенню «бананової» зони. Також надзвичайно перспективною з погляду розвитку транспортно-логістичних кластерів уважається територія так званого «Золотого банану», яка має населення до 45 млн жителів і охоплює територію берегової лінії Середземного моря: італійські міста Генуя і Турін; французькі - Ліон, Марсель, Ніцца, Тулон, Тулуза, далі - Монако і закінчується такими іспанськими містами, як Барселона, Валенсія, Картахена.

Прикладом транспортно-логістичного кластера, що працює на території «Блакитного банану» або, як його ще називають, «гарячий банан» через його яскраве світіння в ночі, можна навести регіональний кластер «Франкфурт-на-Майні» (Німеччина). Цей ТЛК сформувався на основі транспортної системи міста Франкфурта-на-Майні (далі - ТЛК «Франкфурт»). У силу територіальної близькості основних економічних центрів і розвинених транспортних комунікацій регіон Рейн - Майн являє собою соціально-економічно інтегровану високоурбанізовану поліцентричну агломерацію. Економічна міць та інноваційний потенціал регіону Рейн - Майн зіграли чималу роль у тому, що операції ТЛК «Франкфурт» поширилися не тільки далеко за межі міста і землі Гессен, а й за межі національних кордонів Німеччини. У ТЛК «Франкфурт», як у кожному регіональному ТЛК, наявні і пасажирський, i вантажний сектори, але цей ТЛК особливо відомий своїм пасажирським сектором. До компаній, що діють у ТЛК «Франкфурт», належать поряд із такими гігантами, як Deutsche Lufthansa AG та Deutsche Bahn AG, й інші великі компанії, а також велика кількість логістичних компаній сектору малого та середнього бізнесу. Місцеві компанії пропонують і реалізують повний діапазон логістичних послуг - від планування та будівництва логістичних об'єктів та систем до консультативного обслуговування процесів управління рухом потоку матеріалів/вантажів і менеджменту ланцюга поставок. Сучасна інфраструктура місцевих компаній, зокрема 3 інформаційних технологій, допомагає підприємствам логістики в застосуванні систем електронної обробки даних великої потужності, обліку потоків товарів із зазначенням часу та вжиття необхідних заходів безпеки. Експедиторські фірми охоплюють своїм асортиментом увесь спектр послуг із логістики [4, с. 14].

На території «Золотого банану» більш потужні представники портових кластерів, як приклад транспортно-логістичної інфраструктури на цій території можна навести транспортно-логістичний кластер Валенсія.

Цей кластер сформувався на базі «колонії» 3 трьох середземноморських портів Іспанії: порт Валенсія домінуючий порт у колонії (85\% трафіку кластера), порт Сагунто (14\%), порт Гандія (1\%). Ці три порти мають спільну портову адміністрацію. Населення міста Валенсія - 810 тис осіб, метрополії Валенсія - близько 2 млн. Валенсія з'єднана з мережею автомагістралей та залізничною мережею Іспанії. $€$ залізничні під'їзні шляхи до всіх терміналів порту. Наприкінці 2010 р. відкрито високошвидкісну залізничну пасажирську лінію Мадрид - Куенка - Валенсія. Без зупинок потяг долає 
відстань між Мадридом і Валенсією за 1 годину 33 хв. 3 5:00 до 21:00 щодня відправляються 15 поїздів в обох напрямках 3 інтервалом проходження близько однієї години. Аеропорт Валенсія розташований в 9 км від ділового центру міста. Морський порт Валенсія за обсягами контейнерної перевалки займає 28-ту позицію у світі і 5-ту у Європі. У порту є зона логістичних операцій ZAL площею 68 га, де логістичні оператори пропонують повний набір послуг, що забезпечують нерозривність функціонування транспортних ланцюжків. У зоні ZAL організовано субзону для провайдерів транспортно-логістичних послуг сектору малого та середнього бізнесу. Порт Сагунто (30 км на північ від Валенсії) має своїм основним вантажем зріджений природний газ (ЗПГ). Неподалік від міста Сагунто (66 тис населення) розташовується завод регазифікації, на який і надходить ЗПГ із терміналів порту. Інші вантажі - метали, будівельні матеріали, добрива. Порт Гандія (65 км на південь від Валенсії) спеціалізується на перевалці лісоматеріалів та продуктів їх переробки: меблів, паперу тощо. Населення міста Гандія - 80 тис мешканців. Кластер характеризується вигідним транспортно-географічним положенням: 3 усіх середземноморських портів портовий кластер Валенсія є найменш віддаленим від трансокеанського торгового шляху, що з'єднує Атлантику з Індійським океаном. Існує Фонд порту Валенсія (Valenciaport Foundations) - координаційна структура, створена для сприяння розвитку кластера через підтримку Центру передових досліджень, тренінгів та кооперації. Засновниками фонду є: порт Валенсія, регіональний уряд, головний регіональний банк, портове співтовариство (асоціації автоперевізників, експедиторів, агенцій морських перевезень і судновласників), університет Валенсії, ТПП Валенсії, приватні групи [4, с. 14].

Усі види кластерів чудово взаємодіють між собою, при цьому збільшуючи території впливу та залучаючи додаткові інвестиції, одночасно знижуючи ризики для учасників транспортно-логістичних кластерів.

Діяльність ТЛК у країнах Європейського Союзу базується на таких принципах [5]:

- пропозиція максимально повного переліку транспортних і супутніх послуг на основі договірних відносин із кожним учасником логістичного ланцюга (формування банку даних логістичних ланцюгів);

- організація комплексного транспортного обслуговування на основі єдиного договору на комплексне обслуговування й єдине замовлення на всі послуги, формування завдань для учасників логістичного ланцюга на підставі замовлення користувача транспортних послуг, централізований контроль виконання замовлення;

- максимальна стандартизація та уніфікація перевізних та інших документів, необхідних для виконання перевезення, що застосовуються учасниками логістичних ланцюгів, із метою забезпечення можливості створення єдиного інформаційного простору;

- єдина маркетингова стратегія i тактика учасників логістичного ланцюга на ринку транспортних послуг, спільне проведення дослідження ринків і маркетингових заходів, що забезпечують просування всіх учасників логістичного ланцюга на ринку транспортних послуг і формування попиту на комплексні транспортні послуги;
- географічний розподіл структурних підрозділів кластера 3 метою максимального охоплення ринку транспортних послуг, виконання оперативного управління роботою логістичних ланцюгів у місцях формування вантажопотоків та їх перетину;

- побудова роботи на основі світових стандартів і міжнародних договорів, угод, конвенцій;

- інтеграція 3 міжнародними логістичними центрами і забезпечення інформаційного обміну;

- стандартизація інформаційної взаємодії логістичних ланцюгів учасників ТЛК.

В Україні сьогодні діє близько 50 кластерів у таких галузях економіки, як туризм, добуток і переробка каменю, деревообробка, виробництво трикотажних виробів, виноробство, машинобудування, й охоплює такі області, як Хмельницька, Івано-Франківська, Черкаська, Житомирська, Одеська, Харківська, Рівненська, Херсонська, Закарпатська. На нашу думку, недостатньо уваги приділяється розвитку транспортно-логістичних кластерів, а саме вони $є$ оптимальним типом кластерів для початкового етапу кластеризації економіки.

Ураховуючи євровекторність економіки України, геополітичне положення, розташування нашої країни щодо глобальних економічних центрів, відстань до цих центрів, загальну протяжність кордону країни (6 992,982 км), рівень транскордонності (80\% областей $\epsilon$ прикордонними, спільні кордони із сімома країнами Європи), пропускну спроможність автомобільних магістралей, що входять у систему міжнародних транспортних коридорів (МТК) на території України, якість внутрішньої транспортної мережі (57-е місце в глобальному рейтингу серед 141 країн у 2018-2019рр.), можна стверджувати про великі потенційні можливості нашої країни щодо створення транспортно-логістичних кластерів.

Але без державної підтримки, особливо на етапі розвитку, неможливо досягти відповідного рівня кластеризації, при цьому ініціатором можуть виступати не тільки підприємницькі структури, а й органи регіональної влади, центральні органи управління. Державна підтримка транспортно-логістичних кластерів необхідна під час формування стратегічних напрямів державної підтримки, відповідної нормативної бази, створення необхідних економічних важелів, сприятливого нормативно-правового інвестиційного клімату, забезпечення високого потенціалу кадрів, інформаційної підтримки.

Більшість країн Європи для стимулювання економічного розвитку на основі кластеризації розробляє кластерні стратегії, які є елементом національної стратегії, для підвищення конкурентоздатності країни, або регіональної програми для стабілізації регіонального розвитку [6].

Висновки. У статті проаналізовано теоретичні i практичні засади щодо формування транспортнологістичних кластерів у країнах СС, визначено вплив наявності в регіоні транспортно-логістичних кластерів на його інтеграційні можливості та потенціал зростання соціально-економічної сфери.

Виявлено необхідність державної підтримки формування транспортно-логістичних кластерів, особливо на етапі розвитку, окреслено інструменти і рівень такої підтримки. 


\section{Список використаних джерел:}

1. Портер М.Э. Конкуренция / пер. с англ. Москва : Вильямс, 2005. 608 с.

2. Swann, G.M.P. and Prevezer, M. (1996) A Comparison of the Dynamics of Industrial Clustering in Computing and Biotechnology, Research Policy. № 25, pp. 1139-1157.

3. Мандра В.В. Аналіз світового досвіду управління транспортно-логістичним центром. Економічний аналіз. 2016. Т. 24. № 2. C. $92-97$.

4. Смирнов І., Шматок О. Формування транспортно-логістичних кластерів у СС: український контекст. Вісник Київського національного університету імені Т.Г. Шевченка. 2012. Вип. 60. С. 14-19.

5. European Alternative Fuels Observatory : web-site. URL: https://www.eafo. eu/alternative-fuels/electricity/charging-infra-stats (дата звернення: 21.02.2021).

6. Тарнавська Н.П., Сивак Р.Б. Організаційні та інфраструктурні передумови створення міжнародного логістичного центру. Бізнес Інформ. 2013. № 13. С. 29-35.

\section{References:}

1. Porter M. (2005) Konkurentsiya [Competition]. Moscow: Williams. (in Russian)

2. Swann G.M.P., Prevezer M. (1996) A Comparison of the Dynamics of Industrial Clustering in Computing and Biotechnology. Research Policy, no. 25, pp. 1139-1157.

3. Mandra V.V. (2016) Analiz svitovogho dosvidu upravlinnja transportno-loghistychnym centrom [Analysis of world experience in transport and logistics center management]. Ekonomichnyj analiz : zb. nauk. pracj. Ternopilj : Vydavnycho-polighrafichnyj centr Ternopiljsjkogho nacionaljnogho ekonomichnogho universytetu "Ekonomichna dumka", vol. 24, no. 2, pp. 92-97.

4. Smyrnov I., Shmatok O. (2012) Formuvannja transportno-loghistychnykh klasteriv u JeS: ukrajinsjkyj kontekst [Formation of transport and logistics clusters in the EU: Ukrainian context]. Bulletin of the Kiev National University Shevchenko, vol. 60, pp. 14-19.

5. European Alternative Fuels Observatory. URL: https://www.eafo. eu/alternative-fuels/electricity/charging-infra-stats (accessed 21 February 2021).

6. Tarnavsjka N.P., Syvak R.B. (2013) Orghanizacijni ta infrastrukturni peredumovy stvorennja mizhnarodnogho loghistychnogho centru [Organizational and infrastructure prerequisites for the creation of an international logistics center]. Biznes-Inform, no. 13, pp. 29-35.

Lutsenko Iryna
National Technical University of Ukraine
"Igor Sikorsky Kyiv Polytechnic Institute»

\section{EUROPEAN INTEGRATION AS A FACTOR IN THE DEVELOPMENT OF TRANSPORT AND LOGISTIC CLUSTERS IN UKRAINE}

The article considers the prospects of clustering of transport and logistics system of Ukraine, analyzes the main characteristics of transport and logistics clusters, forms the paradigm of state regulation of transport and logistics clusters and identifies and justifies its need, especially at the cluster development stage, identifie s basic tools of state support. In order to determine the effectiveness of economic clustering processes, the experience of European countries in the creation and operation of transport and logistics clusters is considered, their importance for clustering of the whole economy is determined, features, internal and external factors, mechanisms and drivers of transport and logistics clusters of different types are systematized. the most promising European areas for the development of transport and logistics clustering, namely the area of "Blue" and "Golden Banana". It is determined that this region has good prospects for further development, is extremely attractive for large investments, which contributes to the expansion of the "banana" zone, we can predict that in the near future we will see the growth and integration of these zones. These trends significantly intensify the socio-economic development of countries that are part of the "banana" zone. Transport and logistics clusters are considered in terms of regional reproduction and increase the efficiency of all other clusters by creating a reliable framework for transportation of products and logistics services. Lack, insufficient capacity, low efficiency of transport and logistics clusters determines the low level of socio-economic development of the country and the separation of the region from global integration processes, the loss of geopolitical and geostrategic influence. Powerful transport and logistics clusters are able to significantly increase the transit potential of the region, improve the quality of life, revive investment activity, reduce unemployment, improve staff skills, promote innovation in the development of the region, increase budget revenues and budgets at various levels. . It is proposed to accelerate the process of intensifying the development of troubled markets and regions of Ukraine through the creation of transport and logistics clusters, which will be the basis for the overall clustering of Ukraine's economy.

Key words: transport and logistics cluster, clustering, state regulation of transport and logistics clusters, European integration, regional cluster, port cluster. 